\title{
PENGARUH MODEL PEMBELAJARAN COOPERATIVE TIPE GROUP INVESTIGATION BERBANTUAN MEDIA GAMBAR TERHADAP PRESTASI BELAJAR SISWA KELAS VIII SMP NEGERI 3 SOE
}

\author{
Matheos J. Takaeb ${ }^{1,},{ }^{*}$, Ferdinandus Mone ${ }^{1}$ \\ ${ }^{1}$ Program Studi Pendidikan Biologi, Program Studi Pendidikan Matematika, \\ Sekolah Tinggi Keguruan dan Ilmu Pendidikan Soe, TTS-NTT. 85511 \\ *email korespondensi: mathewtakaeb@gmail.com
}

\begin{abstract}
ABSTRAK
Penelitian ini bertujuan untuk menguji pengaruh model pembelajaran kooperatif tipe Group Investigation berbantuan media gambar terhadap prestasi belajar siswa kelas VII SMP Negeri 3 Soe. Hasil kesamaan uji rata-rata menggunakan independent sample $t$-test menunjukan nilai signifikan 0,45>0,05 dan uji homogenitas menunjukan bahwa 0,847 $>0,05$ yang berarti sebaran data antara dua kelompok sampel sama secara statistik. Dengan demikian, kedua kelas tersebut dapat dilaksanakan penelitian dengan penerapan model GI pada kelas eksperimen. Teknik analisis data yang digunakan dalam penelitian ini adalah one sample t-test untuk mengetahui ketuntasan belajar siswa. Independent sample t-test untuk mengetahui rata-rata prestasi siswa pada kelas eksperimen apabila dibandingkan kelas kontrol. Paired sample t-test untuk mengetahui peningkatan prestasi belajar siswa setelah diberikan model GI. Uji T-test dan uji regresi untuk mengetahui pengaruh model $G$ I terhadap peningkatan prestasi belajar siswa. Hasil penelitian menunjukkan bahwa hasil uji ketuntasan menunjukkan nilai thitung 14,877>ttabel 1,76131. diketahui juga, bahwa uji ketuntasan individual menunjukkan nilai sig. 0,000 $<0,005$ sehingga hipotesis diterima. Artinya rata-rata prestasi siswa melampaui KKM yang ditetapkan yaitu 70 . Hasil uji peningkatan rata-rata prestasi kelas eksperimen menunjukan Nilai sig. $<0,05$ sehingga ada perbedaan antara kelas kontrol dan kelas eksperimen yakni $(52,58)$ dan sesudah perlakuan $(86,55)$.
\end{abstract}

Kata-kata kunci: Group Investigation; media gambar; prestasi belajar siswa

\section{PENDAHULUAN}

Sekolah sebagai lembaga pendidikan yang memiliki peranan penting dalam upaya pengembangan dan peningkatan sumber daya manusia. Pencapaian keberhasilan dalam pembelajaran ditentukan oleh kualitas proses pembelajaran yang dialami oleh siswa. Oleh sebab itu, dibutuhkan strategi yang tepat untuk mengarahkan kegiatan pembelajaran, strategi dalam proses pembelajaran diantaranya adalah penggunaan model pembelajaran dalam membantu ketercapaian tujuan pembelajaran, pemilihan dan penggunaan model pembelajaran yang tidak tepat akan menghambat proses pembelajaran dan mengakibatkan penggunaan waktu yang tidak efisien.

Proses pembelajaran yang terjadi di SMP Negeri 3 SoE, pada mata pelajaran IPA terpadu dalam kesehariannya guru tidak menggunakan model pembelajaran seperti model pembelajaran dengan menggunakan media gambar. Namun, memperhatikan kelemahan guru dalam menggunakan media gambar, hasil belajar siswa menurun dan kemampuan kognitif siswa kurang terlatih dalam mengemukakan ide-idenya untuk memecahkan suatu masalah. Karena kurangnya interaksi antar siswa dan guru dalam proses pembelajaran, hal ini menyebabkan siswa menjadi pasif dan rasa ingin tahu siswa rendah.

Berdasarkan hasil wawancara dengan guru mata pelajaran IPA terpadu masih terdapat banyak siswa yang belum mencapai KKM (70). Data yang diperoleh yaitu hanya $25 \%$ siswa yang sudah mencapai KKM. Permasalahan ini dapat diselesaikan dengan membenahi kembali model pembelajaran yang digunakan. Model pembelajaran yang digunakan harus dapat menstimulus siswa agar terliabt aktif dalam proses pembelajaran. Ketika seluruh siswa aktif dalam kegiatan pembelajaran yang berlangsung maka siswa akan termotivasi dan terdorong untuk ingin tahu sehingga dapat memahami dengan benar materi yang disampaikan guru. Permasalahan lain yang terjadi di sekolah adalah kurangnya sumber belajar seperti buku 
cetak dan tidak tersedianya laboratorium IPA di sekolah. Keterbatasan yang dialami guru dalam aspek ketersediaan sarana dan prasarana perlu dilakukan dengan pengajaran yang kreatif dalam memilih dan menerapkan model pembelajaran. Misalnya penggunaan media pembelajaran yang sederhana namun harus mencangkup materi yang hendak dipelajari, untuk menjelaskan hal-hal yang sulit dimengerti oleh siswa apabila hanya dijelaskan dengan ceramah saja, agar pembelajaran yang terjadi terdapat stimulus yang direspon oleh siswa sehingga sejalan dengan apa yang dikatakan oleh Dimyati dan Mudjiono (2006) bahwa dalam tingkah laku belajar terdapat jalinan yang erat antara reaksi-reaksi behavioural dengan stimulusnya.

Penerapan model pembelajaran Group Investigation dapat menstimulus siswa untuk terlibat aktif dalam proses pembelajaran, hal ini disebabkan karena dalam penerapannya, siswa akan belajar secara mandiri dalam kelompok untuk menginvestigasi atau mencari, menemukan, dan menganalisis informasi dari berbagai sumber mengenai materi pembelajaran yang telah dibagikan kepada masing-masing kelompok. Pratiwi, dkk, 2014 mengemukakan bahwa "model Group Investigation lebih menekankan kerja sama antar anggota kelompok dalam menemukan dan memahami suatu konsep dengan melakukan serangkaian kegiatan investigasi sehingga konsep tersebut akan lebih tertanam dalam ingatan siswa", Sehingga terlihat jelas bahwa dalam pembelajaran menggunakan model pembelajaran Group Investigation) guru bertindak sebatas sebagai narasumber dan fasilitator. Dengan demikian pembelajaran yang berpusat pada siswa (student center) akan menstimulus kondisi pembelajaran yang menyenangkan, bermakna, serta menumbuhkan motivasi belajar siswa. Hal ini didukung oleh Sumanik (2015), dalam penelitiannya yang mengatakan bahwa "model pembelajaran Cooperative Group Investigation efektif meningkatkan hasil belajar biologi".

Materi pembelajaran tentang pertumbuhan dan perkembangan mahkluk hidup sangat tepat menggunakan model pembelajaran Group Investigation. Hal ini dikarenakan fase pembelajaran model GI menekankan kerja sama. Selain itu, model Gl juga mengharuskan siswa untuk mencari dan menemukan sendiri solusi dari permasalahan yang diberikan guru, membahas serta menganalisis kebenaran informasi materi pembelajaran. Pertumbuhan dan perkembangan pada makhluk hidup juga terdapat beberapa sub bagian yang harus dibahas, pokok materi pembelajaran seperti ini akan membuang banyak waktu apabila dibahas secara satu persatu namun jika dibagi dan dibahas oleh siswa dalam kelompok, akan mengefektifkan penggunaan waktu pembelajaran.

Media gambar merupakan media pembelajaran visual yang praktis serta mudah untuk digunakan. Yustina (2011) dalam penelitiannya mengemukakan bahwa, media gambar mampu mengatasi batasan lokasi ketika tidak seluruh benda, objek atau peristiwa tidak dimungkinkan untuk dibawa ke kelas. Media gambar juga mampu mengatasi keterbatasan pengamatan kita. Dengan demikian, dapat disimpulkan bahwa media gambar adalah media visual yang mudah dipersiapkan dan mampu memberi gambaran jelas terhadap hal-hal abstrak yang sulit dipahami siswa. Berdasarkan latar belakang di atas, maka perlu dilakukan penelitian yang berjudul "Pengaruh model pembelajaran Cooperative tipe Group Investigation berbantuan media gambar terhadap prestasi belajar siswa kelas VIII SMP Negeri 3 SoE". Tujuan dari penelitian ini adalah untuk mengetahui pengaruh model pembelajaran Cooperative Group Investigation berbantuan media gambar terhadap prestasi belajar siswa kelas VIII SMP Negeri 3 SoE.

\section{METODE PENELITIAN}

Penelitian ini mengambil lokasi di SMP Negeri 3 SoE Jln. Gajah Mada No. 272, KARANG SIRI, Kec. Kota Soe, Kab. Timor Tengah Selatan Prop. Nusa Tenggara Timur. Desain penelitian yang digunakan adalah desain eksperimental sejati (true experimental design) yaitu pre-test-post-test control group design (Furchan, 2007) dapat digambarkan sebagai berikut:

Tabel 1. Gambaran desain penelitian

\begin{tabular}{cccc}
\hline Kelompok & pre-test & Variabel bebas & pre-test \\
\hline I & $\mathrm{Y}_{1}$ & $\mathrm{X}$ & $\mathrm{Y}_{2}$ \\
II & $\mathrm{Y}_{1}$ & - & $\mathrm{Y}_{2}$ \\
\hline
\end{tabular}

\section{Populasi dan Sampel}

Populasi dalam penelitian ini adalah seluruh siswa kelas VIII SMP Negeri 3 SoE dengan siswa yang terbagi atas 4 rombongan belajar. Sampel dalam penelitian ini adalah kelas VIII. dan kelas VIII. SMP Negeri 3 SoE, pemilihan sampel dilakukan secara random (acak) karena pembelajaran di SMP Negeri 3 SoE tidak 
memisahkan kelas unggulan sehingga semua subjek dianggap sama dan mendapat hak yang sama untuk memperoleh kesempatan dipilih menjadi anggota sampel.

\section{Instrumen Penelitian}

Pada tahap persiapan peneliti menyiapkan silabus, rencana pelaksanaan pembelajaran (RPP), serta menyiapkan instrumen penelitian yaitu soal tes awal (pre-test) dalam bentuk pilihan ganda, kemudian soal tersebut diujicobakan terlebih dahulu pada siswa yang berada disekolah tempat penelitian tetapi bukan pada sampel penelitian. Instrumen yang digunakan adalah soal tes (pre-test dan post-test) yang telah diuji validitas dan reabilitas soalnya. Indikator dari setiap instrumen tertuang pada Tabel $\mathbf{2}$.

Tabel 2. Indikator soal materi pertumbuhan dan perkembangan makhluk hidup

\begin{tabular}{|c|c|c|c|}
\hline \multirow[b]{2}{*}{ Indikator } & \multicolumn{3}{|r|}{ Penilaian } \\
\hline & Teknik & $\begin{array}{c}\text { Bentuk } \\
\text { instrumen }\end{array}$ & Contoh Instrumen \\
\hline $\begin{array}{l}\text { - Menyebutkan faktor-faktor yang } \\
\text { mempengaruhi pertumbuhan dan } \\
\text { - Perkembangan makhluk hidup }\end{array}$ & $\begin{array}{l}\text { Tes } \\
\text { tulis }\end{array}$ & Tes & $\begin{array}{l}\text { Tuliskan } 4 \text { faktor yang mempengaruhi } \\
\text { pertumbuhan dan perkembangan pada } \\
\text { makhluk hidup }\end{array}$ \\
\hline $\begin{array}{l}\text { - Menyimpulkan perbedaan pertumbuhan } \\
\text { dan perkembangan pada makhluk hidup. }\end{array}$ & $\begin{array}{l}\text { Tes } \\
\text { tulis }\end{array}$ & Tes & $\begin{array}{l}\text { Deskripsikan perbedaan pertumbuhan } \\
\text { dan perkembangan pada makhluk hidup }\end{array}$ \\
\hline $\begin{array}{l}\text { - Membandingkan metamorfosis dan } \\
\text { metagenesis. }\end{array}$ & $\begin{array}{l}\text { Tes } \\
\text { tulis }\end{array}$ & Tes & $\begin{array}{l}\text { Perubahan bentuk dari berudu hingga } \\
\text { menjadi dewasa disebut }\end{array}$ \\
\hline
\end{tabular}

\section{Teknik Pengumpulan Data}

a. Validitas soal

Persamaan yang digunakan untuk validitas butir soal pilihan ganda (Arikunto, 2009) adalah:

$$
r_{x y}=\frac{N \sum x y-\left(\sum x\right)\left(\sum y\right)}{\sqrt{\left\{N \sum x^{2}-\left(\sum x\right)^{2}\right\}\left\{N \sum y^{2}-\left(\sum y\right)^{2}\right\}}} \cdots
$$

b. Uji reliabilitas soal

Uji reliabilitas soal bentuk pilihan ganda dapat dilakukan dengan menggunakan persamaan KR 20 (Arikunto, 2009).

$$
r_{11}=\left(\frac{n}{n-1}\right)\left(\frac{s^{2}-\sum p q}{s^{2}}\right) \ldots(2) s^{2}=\frac{\sum x^{2}-\frac{\left(\sum x\right)^{2}}{N}}{N} \ldots
$$

c. Analisis item soal

Persamaan yang digunakan untuk menghitung taraf kesukaran adalah (Arikunto 2013) :

$$
P=\frac{\mathrm{B}}{\mathrm{JS}}
$$

Teknik Analisis Data

Uji Statistik yuang digunakan adalalah Uji Ketuntasan (One Sample T-Test), Uji banding/beda (Independent Sample T-Test) dan uji peningkatan (Paired Sample T-Test).

\section{HASIL DAN DISKUSI}

Untuk mengetahui pengaruh model pembelajaran cooperative tipe group investigation berbantuan media gambar maka kelas $\mathrm{VIII}^{2}$ diajarkan menggunakan model pembelajaran cooperative tipe group investigation sedangkan kelas $\mathrm{VIII}^{1}$ dengan model konvensional. Uji normalitas data menggunakan uji Kolmogorof Smirnov (Sukestiarno, 2013). Data hasil penelitian berupa nilai pre-test dan post-test, bertujuan untuk mengetahui perbedaan rata-rata nilai prestasi belajar siswa setelah diberikan perlakuan. Nilai pretest hanya digunakan untuk menguji kemampuan awal sampel. Instrumen yang digunakan berupa soal pilihan 
ganda yang dikerjakan siswa, setelah diterapkan model pembelajaran $G /$ berbantuan media gambar dan model pembelajaran konvensional.

Pengujian terhadap kemampuan awal sampel menggunakan data pre-test, yang dilakukan dengan bantuan aplikasi SPSS menggunakan uji-t (independent sample test), dengan Kriteria $\mathrm{H}_{0}$ diterima jika $\mathrm{t}_{\text {hitung }}<$ $t_{\text {tabel, }}$ pada taraf nyata $\alpha=0,05$ dan $d k=\left(n_{1}+n_{2}-2\right)$ dan untuk harga t lainnya ditolak. Hasil yang diperoleh sesudah diberikan perlakuan pada kelas eksperimen dan kelas kontrol tersajikan pada Tabel 3.

Tabel 3. Rata-rata nilai pre-test dan post-test kelas eksperimen

\begin{tabular}{lc}
\hline \multicolumn{1}{c}{ Kriteria } & Eksperimen \\
Jumlah siswa & 22 \\
Rata-rata pre-test & 52,58 \\
Rata-rata post-test & 86,55 \\
Nilai tertinggi post-test & 95 \\
Nilai terendah post-test & 75 \\
Ketuntasan klasikal(\%) & 70 \\
\hline
\end{tabular}

1. Uji Normalitas

Pengujian normalitas dilakukan berbantuan SPSS menggunakan uji kolmogorov-smirnov dengan derajat signifikansi $5 \%$, dan kriteria $\mathrm{H}_{0}$ diterima jika nilai sig pada uji kolmogorov-smirnov $>\alpha=0,05$ dan sebaliknya $\mathrm{H}_{0}$ ditolak jika nilai sig $<\alpha=0,05$. Berdasarkan hasil uji kolmogorov-smirnov diperoleh nilai sig $0,145>0,05$ sehingga $\mathrm{H}_{0}$ diterima, dengan demikian disimpulkan bahwa data berdistribusi normal. Selanjutnya untuk menyatakan homogenitas diperoleh nilai sig. 0,847 >0,05. Jadi dapat disimpulkan bahwa data bersifat homogen. Sehingga nilai rata-rata kemampuan secara statistik diperoleh nilai sig. $0,485>0,05$. Selanjutnya hasil post-test diperoleh nilai sig. 0,349 $>0,05$ sehingga dapat dikatakan bahwa data berdistribusi secara normal.

2. Uji Ketuntasan Individual

Uji ketuntasan individual digunakan untuk mengetahui rata-rata data akhir pada kelas sampel mencapai ketuntasan individual atau tidak. Uji ketuntasan individual menggunakan uji rata-rata satu pihak yaitu pihak kanan. Dari analisis data yang diperoleh ditemukan nilai $t_{\text {hitung }} 14,877>t_{\text {tabel }} 1,76131$, sehingga hipotesis diterima. Artinya rata-rata prestasi siswa melampaui KKM yang ditetapkan yaitu 70.

3. Uji Banding

Setelah dilakukan uji prasyarat dan nilai kedua kelas sampel berdistribusi normal serta homogen, maka selanjutnya untuk pengujian perbedaan rata-rata menggunakan uji statistik parametrik dengan bantuan SPSS menggunakan uji-t (independent sample test), dengan kriteria pengujian jika $t_{\text {hitung }}$ $\leq t_{\text {tabel }}$ maka $\mathrm{H}_{0}$ diterima dan jika $t_{\text {hitung }} \geq t_{\text {tabel, }}$ maka $\mathrm{H}_{1}$ ditolak. Dari daftar distribusi t diperoleh nilai $t_{\text {hitung }}$ 2,073 > tabel 2,028 sehingga $\mathrm{H}_{0}$ ditolak dan $\mathrm{H}_{1}$ diterima. Jadi dapat katakan bahwa perbandingan sebelum perlakuan dengan menggunakan model pembelajaran dan setelah menggunakan pembelajaran ditemukan perbedaan rata-rata pre-test $(52,58)$ dan post-test $(86,55)$

4. Uji Homogenitas

Uji prasyarat homogenitas dilakukan menggunakan uji Levene dengan taraf signifikan $\alpha=0,05$. Berdasarkan uji Levene untuk homogenitas kedua sampel penelitian diperoleh nilai sig $=0,515$. Karena signifikan $=0,515>0,05$ maka $\mathrm{H}_{0}$ diterima, sehingga dapat disimpulkan bahwa data nilai posttest kedua kelas sampel penelitian berasal dari populasi yang homogen.

5. Uji T-test

Setelah dilakukan uji prasyarat dan nilai kedua kelas sampel berdistribusi normal serta homogen, maka selanjutnya untuk pengujian perbedaan rata-rata menggunakan uji statistik parametrik dengan bantuan SPSS menggunakan uji-t (independent sample test), dengan kriteria pengujian jika $t_{\text {hitung }}$ $\leq t_{\text {tabel }}$ maka $\mathrm{H}_{0}$ diterima dan jika $t_{\text {hitung }} \geq t_{\text {tabel, }}$ maka $\mathrm{H}_{1}$ ditolak. Dari daftar distribusi t diperoleh nilai $t_{\text {hitung }}$ 2,073 $>t_{\text {tabel }}$ 2,028 sehingga $\mathrm{H}_{0}$ ditolak dan $\mathrm{H}_{1}$ diterima.Dengan demikian sesuai dengan hipotesis yang ada dapat disimpulkan bahwa ada perbedaan yang signifikan antara rata-rata prestasi belajar siswa pada kelas yang diterapkan model pembelajaran $G$ l berbantuan media gambar kelas eksperimen dan kelas kontrol. 
6. Uji Regresi

Pada tahap ini uji regresi digunakan untuk untuk menentukan pengaruh sebuah variabel bebas (independent) terhadap variabel terikat (dependent). Menghitung nilai estimasi rata-rata dan nilai variabel terikat berdasarkan pada nilai variabel bebas. Dari hasil yang diperoleh ditemukan pengaruh pada model pembelajaran konvensional dengan model pembelajaran cooperative group investigation sebesar $62,5 \%$. Prestasi siswa dipengaruhi oleh model pembelajaran yang diterapkan sedangkan sisanya dipengruhi oleh factor lain. Adapun Nilai sig untuk model pembelajaran $0,00<0,05$ yang berarti model pembelajaran berpengaruh positif terhadap prestasi belajar siswa. Data ini didukung dengan hasil model regresi yang diperoleh: $\hat{Y}=0,99 X+48,055$ yang berarti setiap kenaikan 1 satuan pada aspek model pembelajaran menaikan prestasi sebesar 0,4999 satuan.

Secara kuantitatif dapat dipahami bahwa kelas yang diajar menggunakan model pembelajaran GI berbantuan media gambar (kelas eksperimen) memiliki nilai rata-rata lebih tinggi dibandingkan dengan kelas yang diajar menggunakan model pembelajaran konvensional (kelas kontrol). Hal ini didukung dengan ketuntasan individu pada masing-masing kelas yakni kelas eksperimen persentasi ketuntasan mencapai 70.

Model pembelajaran $G /$ berbantuan media gambar yang diterapkan pada kelas eksperimen membuat siswa terlibat aktif dalam proses pembelajaran, dikarenakan siswa secara mandiri dalam kelompok melakukan kegiatan penyelidikan terhadap topik materi yang disajikan oleh guru. Siswa melakukan investigasi terhadap tahapan perkembangbiakan pada hewan dengan bantuan media gambar. Dalam proses pembelajaran, setiap anggota kelompok saling bekerja sama dalam melakukan investigasi, serta analisis terhadap topik bergambar yang diperoleh. Hal ini dilakukan sehingga tercipta interaksi dalam kelompok. Ditemukan secara leluasa siswa dapat bertanya dan mengemukakan pendapat kepada teman sebayanya.

Model pembelajaran $G$ lebih mengarahkan siswa secara aktif untuk mandiri dalam menemukan informasi, dan solusi dari topik yang didapatkan dari guru. Pendapat ini didukung dengan penelitian Wuryani (2017) bahwa pembelajaran dengan model GI dapat membuat siswa menjadi lebih aktif dalam pembelajaran. Siswa dituntut untuk berfikir lebih dan terpacu dalam berkompetisi dengan siswa yang lain, sehingga tidak bosan dalam mengikuti pembelajaran. Hal ini yang menjadikan hasil belajar IPA siswa menjadi meningkat. Penelitian di SMP Negeri 3 Soe, dengan model pembelajaran GI melalui kegiatan presentasi kelas dan kegiatan investigasi memberi nilai lebih kepada siswa karena, melatih siswa untuk lebih berani mengemukakan pendapat, dan juga membuat siswa untuk benar-benar memahami materi yang dibahas. Kegiatan tanya jawab saat presentasi mengakibatkan terciptanya diskusi kelas.

Media gambar tahapan perkembangan hewan (ubur-ubur, katak, belalang, dan kupu-kupu) serta gambar peristiwa akibat faktor yang mempengaruhi pertumbuhan dan perkembangan pada makhluk hidup, yang dipadukan dalam penerapan model pembelajaran $G I$ juga membantu siswa lebih memahami dan mengerti akan hal-hal abstrak. Yuswanti (2014) menegaskan bahwa dengan menggunakan media gambar aktivitas siswa menjadi meningkat dan siswa lebih mudah memahami materi yang diajarkan, karena siswa tertarik dengan media yang digunakan dalam pembelajaran.

Berdasarkan pemaparan di atas maka dapat dikatakan bahwa pembelajaran dengan model pembelajaran $G$ adalah pembelajaran yang berpusat pada siswa. Sejalan dengan pernyataan Antika (2014) bahwa pembelajaran yang berpusat pada siswa (student center) membina siswa untuk belajar, berpikir dan mencari informasi sehingga dalam proses pembelajaran tercipta suasana yang aktif dan kreatif. Dengan proses yang dialami siswa ini transfer pengetahuan bisa berjalan dengan optimal karena siswa mengalami sendiri.

\section{KESIMPULAN}

Berdasarkan hasil dan pemaparan di atas dapat disimpulkan bahwa ada perbedaan yang signifikan dari rata-rata prestasi belajar siswa yang diajar menggunakan model pembelajaran Gl (kelas eksperimen) dengan rata-rata prestasi belajar siswa yang di ajar menggunakan model pembelajaran konvensional (kelas kontrol). Dapat diketahui dari nilai $t_{\text {hitung }} 2,073>t_{\text {tabel }} 2,028$ dan rata-rata sebelum perlakuan $(52,58)$ dan sesudah diterapkan perlakuan $(86,55)$, serta model regresi yang diperoleh: $\hat{Y}=0,99 X+48,055$ yang berarti setiap kenaikan 1 satuan pada aspek model pembelajaran menaikan prestasi sebesar 0,4999 
satuan. Perbedaan ini menunjukan bahwa penerapan model pembelajaran $G /$ berbantuan media gambar berpengaruh terhadap prestasi belajar siswa kelas VIII SMP Negeri 3 Soe.

\section{UCAPAN TERIMA KASIH}

Penulis mengucapkan terima kasih kepada RISTEK DIKTI yang telah memberikan dana hibah penelitian pada tahun anggaran 2017, serta STKIP Soe yang telah memberikan kesempatan kepada peneliti untuk dapat melaksanakan penelitian.

\section{DAFTAR PUSTAKA}

Antika R. R. 2014. Proses Pembelajaran Berbasis Student Centered Learning (Studi Deskriptif di Sekolah Menengah Pertama Islam Baitul 'Izzah, Nganjuk). BioKultur, 3(1).

Arikunto, S., 2009. Prosedur Penelitian Suatu Pendekatan Praktik: Edisi Revisi 6. Jakarta : Rineka Cipta.

Arikunto, S. 2013. Prosedur Penelitian: Suatu Pendekatan Praktik. Jakarta: Rineka Cipta.

Dimyati dan Mudjiono. 2006. Belajar dan Pembelajaran. Jakarta: Rineka Cipta.

Pratiwi, F.A. 2014. "Pengaruh Penggunaan Model Discovery Learning Dengan Pendekatan Saintifik Terhadap Keterampilan Berpikir Kritis Siswa SMA". Skripsi. S1 Jurusan Pendidikan MIPA. Universitas Tanjungpura. Pontianak.

Sukestiyarno. 2013. Olah Data Penelitan berbantuan SPSS. Semarang: UNNES

Sumanik, M. 2015. Penggunaan Model Pembelajaran Group InvestigationUntuk Mencapai Kompetensi Belajar Biologi Materi Sistem Peredaran Darah Manusia pada Siswa Kelas VIII SMP st. Theresia langgur - Maluku Tenggara. Biopendix, 1 (2).

Wuryani. 2017. Peningkatan Hasil Belajar IPA dengan Model Kooperatif Tipe Group Investigation Pada Siswa Kelas V SD. E-jurnal mitra pendidikan, 1(5).

Yustina. 2011. Kelebihan dan Kekurangan Media Gambar Terterah. diunduh di http://www.jejakpendidikan.com/2016/08/kelebihan-dan-kelemahan-media-gambar.html. Diakses tanggal 21 April 2017

Yuswanti. 2014. Pengunaan Media Gambar Untuk Meningkatkan Hasil Belajar Siswa pada Pembelajaran IPS di Kelas IV SD PT. Lestari Tani Teladan (LTT) Kabupaten Donggala. Jurnal Kreatif Tadulako, 3(4). 